\title{
HEAVY METAL CONTAMINATION IN WATER AND FISHES FROM THE SHITALAKHYA RIVER AT NARAYANGANJ, BANGLADESH
}

\author{
Anjuman Irin, Md. Sirajul Islam, Md. Humayun Kabir and M. Enamul Hoq ${ }^{1 *}$ \\ Department of Environmental Science and Resource Management, \\ Mawlana Bhashani Science and Technology University, \\ Tangail-1902, Bangladesh
}

River pollution has been a major problem in Bangladesh as industrial growth has led to increase which use lot of chemicals as raw materials. Moreover, anthropogenic activities continuously increase the amount of heavy metals in the water bodies especially in the lakes, canals, rivers and in aquatic organisms which is an alarming rate and has become an worldwide problem (Malik et al. 2010). Aquatic organisms such as fish and shell fish accumulate metals to concentrations many times higher than present in water or sediment (Gumgum et al. 1994). The river port of Narayanganj is one of the oldest ports in Bangladesh. There are also a number of industrial units on its banks, including the cement factory, jute mills etc. Industrial effluent dumped into the river resulting in high levels of pollution is a cause for concern (Murshed 2012). For this reason, the investigation of physico-chemical parameters of water and heavy metal contamination in water and fishes of the Shitalakhya river is essential since even slight changes in their concentration above the acceptable levels can result in serious environmental and subsequent health problems. With this incentive, the present study was attempted to investigate the status of heavy metal pollution in water and fish of the Shitalakhya river near Narayanganj city.

The study area was selected at the Bandar ghat as St-1 and Dhakeshwari ghat as St-2 in the Shitalakhya river at Narayanganj from March to May, 2015. Samples were collected during pre-monsoon and monsoon seasons. To analyze the water quality, $500 \mathrm{ml}$ of water was collected in plastic bottles with double stoppers from each sampling site. The sample bottles were pre-conditioned with $5 \% \mathrm{HNO}_{3}$ and later the bottles were rinsed thoroughly with distilled de-ionized water at least three times before sampling was done. Samples were acidified with $10 \% \mathrm{HNO}_{3}$, were placed in an ice bath and were brought to the laboratory. The samples were filtered through a $0.45 \mu \mathrm{m}$ micro-pore membrane filter and were kept at freeze to avoid further contamination until analysis. In this study

*Author for correspondence: hoq_me@yahoo.com ${ }^{1}$ Bangladesh Fisheries Research Institute, Mymensingh-2201, Bangladesh.

(C) 2016 Zoological Society of Bangladesh DOI: 10.3329/bjz.v44i2.32766 
this study, two commonly available fish species, shing (Heteropneustes fossilis) and taki (Channa punctatus) were collected for two months (March and May). The water quality parameters such as temperature and $\mathrm{pH}$ were determined by the thermometer and digital pH meter (model-pH Scan WP), respectively. Electric conductivity (EC) and total dissolved solids (TDS) were determined by digital EC meter and digital TDS meter (model-HM digital, Germany), respectively. Dissolve oxygen (DO) was determined by digital DO meter (model-D 46974, Taiwan). Alkalinity was measured by titration method and the EDTA method was used to determine the hardness of water. The biological oxygen demand (BOD) was measured by two steps where initial $\mathrm{BOD}\left(\mathrm{BOD}_{1}\right)$ was measured immediately after collection and after 5 days $\left(\mathrm{BOD}_{5}\right)$ was measured by incubation in the dark condition at $20^{\circ} \mathrm{C}$ for 5 days. Then the total $\mathrm{BOD}\left(\mathrm{BOD}_{1}-\mathrm{BOD}_{5}\right)$ was measured according to Trivedy and Goel (1984) and Haq and Alam (2005). The heavy metal as cadmium $(\mathrm{Cd})$, copper $(\mathrm{Cu})$ and lead $(\mathrm{Pb})$ in water were determined with the help of Atomic Absorption Spectrophotometer (AAS) and chromium (Cr), copper $(\mathrm{Cu})$, lead $(\mathrm{Pb})$ and zinc $(\mathrm{Zn})$ in fish samples were analyzed by using UNICAM929 atomic absorption spectrophotometer.

The water color in the Shitalakhya river was almost black with bad smell during the study period. The fluctuation in river water temperature usually depends on the season, geographic location, sampling time and temperature of effluents entering the stream (Ahipathy and Puttaiah 2006). The temperature found from two different sampling sites indicated gradual increase in water temperature which was within the standard limit for uses of all purposes (Table 1). The highest temperature $\left(32.5^{\circ} \mathrm{C}\right)$ was observed in $\mathrm{St}-1$ in April and the lowest $\left(29.9^{\circ} \mathrm{C}\right)$ in St-2 in March. The EC depends on the presence of ions, their total concentrations, and their mobility along with the changing temperature (Greenberg et al. 1992). The lowest EC $(443 \mu \mathrm{S} / \mathrm{cm})$ was observed in St-1 in April and the highest $(1175 \mu \mathrm{S} / \mathrm{cm})$ in St-2 in March.

According to ADB (1994), the standard level of EC for fisheries and irrigation purposes are 1000 and $750 \mu \mathrm{S} / \mathrm{cm}$, respectively. All the EC values are higher than the standard level, indicated the presence of ionic compounds in water. According to Islam et al. (2014), the EC values of some peripheral rivers of Dhaka city ranged from $53.1-65.1 \mu \mathrm{Scm}$ in winter and $11.7-71.8 \mu \mathrm{Scm}$ in summer. Adequate DO is necessary for good water quality, survival of aquatic organism and decomposition of waste by microorganism (Islam et al. 2010). From the present study, the highest value of DO $(2.63 \mathrm{mg} / 1)$ was observed in St-2 in March and the lowest $(1.3 \mathrm{mg} / \mathrm{l})$ was observed in St-1 in May (Table 1). According to De (2005), the standard level of DO for fishing and drinking purposes is 4-6 mg/l. The DoE (2001) found that both the Balu and the 
Shitalakhya rivers are heavily polluted with organic and human wastes, especially during the dry season, as indicated by the low values of DO and high values of coliform bacteria. Since 1989, the DO concentration in the Balu river had been much below the critical level of $4 \mathrm{mg} / 1$ and in Shitalakhya river, the DO values had been frequently below $4 \mathrm{mg} / 1$ since 1997. The DO, below $2 \mathrm{mg} / 1$ may lead to the death of most fish (Meghla et al. 2013). The greater the BOD,

Table 1. Water quality parameters in Shitalakhya river

\begin{tabular}{|c|c|c|c|c|}
\hline \multirow{2}{*}{ Parameters } & \multirow{2}{*}{$\begin{array}{l}\text { Sampling } \\
\text { months }\end{array}$} & \multicolumn{2}{|c|}{ Sampling sites } & \multirow{2}{*}{$\begin{array}{c}\text { Standard } \\
\text { level }\end{array}$} \\
\hline & & St-1 & St-2 & \\
\hline \multirow[t]{3}{*}{ Temp. $\left({ }^{\circ} \mathrm{C}\right)$} & March & 30.1 & 29.9 & 25 \\
\hline & April & 32.5 & 32.3 & (EPA 2001) \\
\hline & May & 32.3 & 31.8 & \\
\hline \multirow[t]{3}{*}{$\mathrm{pH}$} & March & 7.4 & 7.59 & $6.5-8$ \\
\hline & April & 7.7 & 7.7 & (EPA 2001) \\
\hline & May & 7.43 & 7.55 & \\
\hline \multirow[t]{3}{*}{$\mathrm{EC}(\mu \mathrm{S} / \mathrm{cm})$} & March & 1167 & 1175 & $750-1000$ \\
\hline & April & 1139 & 1148 & (ADB 1994) \\
\hline & May & 443 & 479 & \\
\hline \multirow[t]{3}{*}{$\mathrm{DO}(\mathrm{mg} / 1)$} & March & 2.3 & 2.4 & $4-6$ \\
\hline & April & 2.6 & 2.63 & (De 2005) \\
\hline & May & 1.3 & 1.7 & \\
\hline \multirow[t]{3}{*}{ BOD (mg/l) } & March & 1.1 & 1.0 & $5-7$ \\
\hline & April & 1.2 & 1.3 & (EPA 2001) \\
\hline & May & 0.55 & 0.63 & \\
\hline \multirow[t]{3}{*}{ TDS (mg/1) } & March & 378 & 573 & $450-1000$ \\
\hline & April & 557 & 554 & (ADB 1994) \\
\hline & May & 269 & 283 & \\
\hline \multirow[t]{3}{*}{ Alkalinity (mg/l) } & March & 293 & 313 & 200 \\
\hline & April & 330 & 350 & (Bhatnagar et al. \\
\hline & May & 204 & 283 & 2004) \\
\hline \multirow[t]{3}{*}{ Hardness (mg/1) } & March & 72 & 82 & 123 \\
\hline & April & 78 & 86 & (Haq and Alam \\
\hline & May & 65.9 & 73 & 2005) \\
\hline
\end{tabular}

the more rapidly oxygen is depleted in the stream (Abida and Harikrishna 2008). The highest value of BOD (1.3 mg/l) was observed in St-2 in April and the lowest $(0.55 \mathrm{mg} / 1)$ was in St-1 during May. According to the EPA (2001) the standard level of BOD for surface water and fisheries are $5-7$ and $3-6 \mathrm{mg} / 1$, respectively. The standard level of TDS for drinking, irrigation and fish culture purposes are 1000, 2000 and $450 \mathrm{mg} / 1$, respectively. The highest value of TDS (573 mg/1) was observed in St-2 in March and the lowest $(269 \mathrm{mg} / \mathrm{l})$ was observed in St-1 during May. All of the observed TDS values are within the standard level for drinking, irrigation water and fish culture. Hardness of water 
is due to the presence of chloride, sulfate, carbonate, bicarbonate salts of $\mathrm{Ca}^{2+}$ and $\mathrm{Mg}^{2+}$ and the hardness increases in dry season and decreases in wet season (Rahman et al. 2012). The highest value ( $86 \mathrm{mg} / \mathrm{l}$ ) was observed in $\mathrm{St}-2$ in April and the lowest $(65.9 \mathrm{mg} / 1)$ was observed in St-1 during May that reflects the hardness of water fluctuates with time (Table 1).

The highest alkalinity of $350 \mathrm{mg} / 1$ at St- 2 and the lowest of $204 \mathrm{mg} / 1$ at St-1 were found in April and May, respectively. All the values were greater than the standard level of alkalinity for surface water that is $200 \mathrm{mg} / 1$ (Bhatnagar et al. 2004). It indicates that Shitalakhya river contains higher amounts of carbonates and bi-carbonates enriched compounds. According to Ahmed et al. (2010a), alkalinity ranged from $5.64 \mathrm{mg} / 1$ in pre-monsoon and $121.0 \mathrm{mg} / 1$ in postmonsoon in the Karnafuli river, which differed from the values of present study due to the chemical characteristics of pollutant in the Karnafuli which contains mostly acidic compounds. All of the observed $\mathrm{pH}$ values are lower than the standard level. According to Islam et al. (2014) the $\mathrm{pH}$ values of some peripheral rivers of Dhaka city ranged from 5.7- 8.2 in winter and 6.5 - 7.8 in summer.

Table 2. The concentration (ppm) of lead $(\mathrm{Pb})$, cadmium (Cd) and copper $(\mathrm{Cu})$ of Shitalakhya river

\begin{tabular}{lcccc}
\hline \multirow{2}{*}{$\begin{array}{l}\text { Heavy } \\
\text { metals }\end{array}$} & Sampling & \multicolumn{2}{c}{ Sampling sites } & Standard level \\
\cline { 2 - 3 } & months & St-1 & St-2 & \\
\hline $\mathrm{Pb}$ & Mar. & 0.021 & 0.025 & $0.05-0.1$ \\
& Apr. & 0.024 & 0.023 & (ADB 1994) \\
& May & 0.023 & 0.022 & \\
$\mathrm{Cd}$ & Mar. & 0.005 & 0.008 & $0.005-0.05$ \\
& Apr. & 0.007 & 0.009 & (ADB 1994) \\
& May & 0.006 & 0.009 & \\
$\mathrm{Cu}$ & Mar. & 0.02 & 0.021 & $0.2-1.0$ \\
& Apr. & 0.025 & 0.027 & (De 2005, ADB \\
& May & 0.025 & 0.027 & $1994)$ \\
\hline
\end{tabular}

The highest value of $\mathrm{Pb}(0.025 \mathrm{ppm})$ was observed in St-2 and the lowest (0.021 ppm) in St-1 in March (Table 2). The standard level of $\mathrm{Pb}$ for drinking, irrigation and fisheries are $0.05,0.1$ and $0.05 \mathrm{ppm}$, respectively. Here, all the observed values are lower than the standard level. Islam et al. (2014) found that the total concentration of $\mathrm{Pb}$ ranged from $0.0029-0.0081 \mathrm{ppm}$ in the rivers adjacent to Dhaka city. Ahmed et al. (2010a) reported that the concentration of $\mathrm{Pb}$ ranged from $0.058 \mathrm{ppm}$ during pre-monsoon to $0.072 \mathrm{ppm}$ during monsoon in the Buriganga river.

Ahmed et al. (2010a) studied that the concentration of $\mathrm{Cd}$ ranged from 0.007 ppm during monsoon to $0.012 \mathrm{ppm}$ during post-monsoon in the Buriganga river. The highest value of $\mathrm{Cd}(0.009 \mathrm{ppm})$ was observed in St-2 in April and May 
and the lowest (0.005 ppm) was observed in St-1 during March (Table 2). According to ADB (1994) the standard level of $\mathrm{Cd}$ for drinking, irrigation and livestock water are $0.05,0.1$ and $0.05 \mathrm{ppm}$, respectively. Here, all the observed values are lower than the standard level that indicated lower level of $\mathrm{Cd}$ pollution. The highest $\mathrm{Cu}(0.027 \mathrm{ppm})$ was observed in St-2 in May and the lowest $(0.020 \mathrm{ppm})$ was observed in St-1 during March (Table 2), which are below the standard level. Islam et al. (2014) found that the highest concentration of $\mathrm{Cu}$ was $0.042 \mathrm{ppm}$ during winter and $0.020 \mathrm{ppm}$ during summer season in the rivers adjacent to Dhaka city. Ahmed et al. (2010a) studied that the concentration of $\mathrm{Cu}$ ranged from $0.11 \mathrm{ppm}$ during monsoon to $0.2 \mathrm{ppm}$ during post-monsoon in the Buriganga river.

During the study period, $\mathrm{Pb}$ was not detected in sampled fish species from Shitalakhya river. Ahmed et al. (2009) investigated the heavy metal concentration in fish and oyster from the Shitalakhya river and found seasonal variation of $\mathrm{Pb}$ ranged from $9.16-13.09 \mathrm{mg} / \mathrm{kg}$ and the highest level of $\mathrm{Pb}$ in chapila (Gudusia chapra) $(13.52 \mathrm{mg} / \mathrm{kg})$ during monsoon and the lowest on tatkeni (Cirrhinus reba) $(8.03 \mathrm{mg} / \mathrm{kg}$ ) during pre-monsoon from the Buriganga river. Ahmed et al. (2010b) studied the heavy metal concentration in fish from Dhaleswari river, Bangladesh and found the seasonal variation of $\mathrm{Pb}$ from 7.03 $12.18 \mathrm{mg} / \mathrm{kg}$. The $\mathrm{Pb}$ was not detected in the fishes under this study, probably due to seasonal variation. Also Cr was not detected in fish species. According to Ahmed et al. (2010b), Cr concentration was highest in chapila $(7.38 \mathrm{mg} / \mathrm{kg})$ during monsoon and the lowest in tengra $(5.27 \mathrm{mg} / \mathrm{kg})$ during monsoon in Buriganga river. Ahmed et al. (2010b) studied the heavy metal concentration in fish from the Dhaleswari river found the seasonal variation of $\mathrm{Cr} 9.38-19.65$ $\mathrm{mg} / \mathrm{kg}$. Ahmed et al. (2009) investigated the heavy metal concentration in fish and oyster from the Shitalakhya river, and found seasonal variation of $\mathrm{Cr}$ ranged from $8.12-9.07 \mathrm{mg} / \mathrm{kg}$. The $\mathrm{Cu}$ values for two fish samples of the Shitalakhya river from the two stations in the months of March and May, 2015 are shown in Table 3. The highest $\mathrm{Cu}(0.76 \mathrm{ppm})$ was observed in Channa punctatus in March at St-1 and the lowest $(0.22 \mathrm{ppm})$ also in C. punctatus in March at St-2. Ahmed et al. (2010b) studied the heavy metal concentration in fish from Dhaleswari river, and found the seasonal variation of $\mathrm{Cu}(7.55-11.50 \mathrm{mg} / \mathrm{kg})$. Ahmed et al. (2010b) studied that $\mathrm{Cu}$ level was the highest $(6.34 \mathrm{mg} / \mathrm{kg})$ in chapila during post monsoon and the lowest in tatkeni $(3.36 \mathrm{mg} / \mathrm{kg})$ during the same time in Buriganga river. Ahmed et al. (2009) investigated the heavy metal concentration in fish and oyster from Shitalakhya river, Bangladesh found seasonal variation of $\mathrm{Cu}$ ranged from $5.47-8.19 \mathrm{mg} / \mathrm{kg}$. All these values differ from the findings of the present study due to different accumulation levels of $\mathrm{Cu}$ in different organs 
of fish and also for abundance of $\mathrm{Cu}$ enriched pollutants in water. The $\mathrm{Zn}$ concentration for fish samples of the Shitalakhya river from two locations in the months from March and May, 2015 are shown in Table 3. Here, the highest value of $\mathrm{Zn}(20.13 \mathrm{ppm})$ was observed in C. punctatus in May at Bandar St-1 and the lowest (6.24 ppm) was observed in H. fossilis at St-2 of the river.

Table 3. Concentration of heavy metal (ppm) of lead ( $\mathrm{Pb})$, chromium $(\mathrm{Cr})$, copper $(\mathrm{Cu})$ and zinc (zn) in fish samples of Shitalakhya river

\begin{tabular}{|c|c|c|c|c|c|}
\hline \multirow[t]{2}{*}{ Fish species } & \multirow{2}{*}{$\begin{array}{l}\text { Heavy } \\
\text { metals }\end{array}$} & \multicolumn{2}{|c|}{ Bandar ghat } & \multicolumn{2}{|c|}{ Dhakeshwari ghat } \\
\hline & & March & May & March & May \\
\hline \multirow[t]{4}{*}{ Heteropneustes fossilis } & $\mathrm{Pb}$ & & & & \\
\hline & $\mathrm{Cr}$ & & & & \\
\hline & $\mathrm{Cu}$ & 0.36 & 0.23 & 0.41 & 0.42 \\
\hline & $\mathrm{Zn}$ & 8.68 & 8.24 & 10.2 & 6.4 \\
\hline \multirow[t]{4}{*}{ Chana punctatus } & $\mathrm{Pb}$ & & & & \\
\hline & $\mathrm{Cr}$ & & & & \\
\hline & $\mathrm{Cu}$ & 0.76 & 0.45 & 0.22 & 0.45 \\
\hline & $\mathrm{Zn}$ & 8.35 & 20.13 & 15.92 & 10.74 \\
\hline
\end{tabular}

From the present study, it can be concluded that the water of Shitalakhya river is partly metal polluted and is unsuitable for drinking, irrigation, fishing, livestock and also recreational purposes. A very few species of fish are now available. So, for the management of water quality of Shitalakhya river near Narayanganj city, rivers water quality and monitoring and legislation on dumping of industrial waste into the river should be established as well as some mitigation measures should also be taken to recover and sustain healthy ecosystem of the river.

\section{LITERATURE CITED}

ABIDA, B. and HARIKRISHNA, R. 2008. Study on the quality of water in some streams of Cauvery river. E-Journal of Chemistry 5(2): 377-384.

ADB (Asian Development Bank). 1994. Training for Environmental Monitoring. Engineering Science Inc., USA. pp. 2-16.

AHIPATHI, M.V. and PUTTAIAH, E.T. 2006. Ecological characteristics of Vishabharathi river in Bangalore (India). Environ. J. Chemistry 5(2): 377-384.

AHMAD, M.K., ISLAM, S., RAHMAN, M.S., HAQUE, M.R. and ISLAM, M.M. 2010a. Heavy metals in water, sediment and some fishes of Buriganga river, Bangladesh. International J. Environ. Res. 4(2): 321-332.

AHMED, M.K., ISLAM, S., RAHMAN, M.S., HAQUE, M.R. and ISLAM, M.M. 2010b. Heavy metal concentration in water, sediments, and their bioaccumulations in fishes and oyster in Dhaleswari river. Asian J. Water Environ. Poll. 7(1): 77-90. 
AHMED, M.K., BHOWMIK, A.C., RAHMAN, S., HAQUE, M.R., HASAN, M.M. and HASAN, A.A. 2009. Heavy metal concentration in water, sediments, and their bioaccumulations in fishes and oyster in Shitalakhya river. Terrestrial Aquatic Environ. Toxicol. 3: 33-41.

BHATNAGAR, A., JANA, S.N., PATRA, B.C., SINGH, G. and BARMA, U.K. 2004. Water quality management in aquaculture. Haryana Agricultural, India. 203-210 pp.

De, A.K. 2005. Environmental chemistry. 5th edition. New Age International Publishers, New Delhi. p. 242.

DoE (Department of Environment). 2001. Water quality data of rivers Buriganga, Meghna, Balu, Shitalakhya and Jamuna. Department of Environment, Dhaka, Bangladesh. 35-40 pp.

EPA (Environmental Protection Agency), United States. 2001. Drinking water criteria document. Final draft. Environmental Criteria and Assessment Office, Cincinnati. pp. 118-288.

GREENBERG, A.E., CLESCERI, L.S. and EATON, A.D. 1992. Standard methods for the examination of water and wastewater. $18^{\text {th }}$ edition. American Public Health association (APHA), Washington, D.C., USA.

GUMGUM, B., UNLU, E., TEZ, Z. and GULSUN, Z. 1994. Heavy metal pollution in water, sediment and fish from the Tigris river in Turkey. Chemosphere 29: 111-116.

HAQ, S.M.I. and ALAM, M.D. 2005. A handbook on analyses of soil, plant and water. BACER-DU, University of Dhaka, Bangladesh. 47 p.

ISLAM, M.M., RAHMAN, S.L., AHMED, S.U. and HAQUE, M.K.I. 2014. Biochemical characteristics and accumulation of heavy metals in fishes, water and sediments of the river Buriganga and Shitalakhya of Bangladesh. J. Asian Sci. Res. 4(6): 270-279.

ISLAM, M.S., SURAVI and MEGHLA, N.T. 2010. Investigation on water quality in the Ashulia beel, Dhaka. Bangladesh J. Fish. Res. 14(1-2): 55-64.

MALIK, N., BISWAS, A.K., QURESHI, T.A., BORANA, K. and VIRHA, R. 2010. Bioaccumulation of heavy metals in fish tissues of a freshwater lake of Bhopal. Environ. Monitor. Assess. 160: 267267.

MEGHLA, N.T., ISLAM, M.S., ALI, M.A. SURAVI and SULTANA, N. 2013. Assessment of physicochemical properties of water from the Turag river in Dhaka city, Bangladesh. International J. Current Microb. and Applied Sci. 2(5): 110-122.

MURSHED, M.M. 2012. Shitalakhya river. In: Islam, S. and A.J. Ahmed. Banglapedia: National Encyclopedia of Bangladesh (Seconded.). Asiatic Society of Bangladesh.

RAHMAN, A.K.M.L., ISLAM, M., HOSSAIN, M.Z. and AHSAN, M.A. 2012. Study of the seasonal variations in Turag river water quality parameters. African J. Pure and Applied Chemistry 6(10): 144-148.

TRIVEDY, R.K. and GOEL, P.K.1984. Practical Methods in Ecology and Environmental Science. Environment Media Publications, Karad. 69-85 pp. 